\title{
Heterologous Expression and Purification of $\beta$ Galactosidase Protein Using Affinity Chromatography
}

\author{
M. Z. Alam ${ }^{1 *}$, L. Regioneiri ${ }^{2}$, M. A. S. Santos ${ }^{2}$, and A. Iqbal ${ }^{1}$ \\ ${ }^{1}$ Department of Genetic Engineering and Biotechnology, Shah Jalal University of Science and \\ Technology, Sylhet-3114, Bangladesh \\ ${ }^{2}$ RNA Biology Laboratory, Department of Biology and CESAM, University of Aveiro, Aveiro \\ 3810-193, Portugal
}

Received 17 February 2013, accepted in final revised form 12 May 2013

\begin{abstract}
Enzymes and other protein purification using recombinant DNA technology have become popular due to scarcity of natural protein. Saccharomyces cerevisiae is a demanding host, since it facilitates protein expression by its relative simplicity, safe organisms, inexpensive and has many properties of eukaryotic expression system. As an alternative host we express E. coli lacZ gene with GST tag in Saccharomyces cerevisiae and successfully purified from soluble extracts. The concentration of soluble GST- $\beta$ galactosidase protein was approximately $0.57 \mathrm{mg} / \mathrm{ml}$ of elution buffer yielded from $50 \mathrm{ml}$ yeast cell culture. The $\beta$ galactosidase protein from insoluble extract was low due to the increasing solubility of GST tag.
\end{abstract}

Keywords: $\beta$-galactosidase; Heterologous expression; GST tag; Affinity chromatography.

๑) 2013 JSR Publications. ISSN: 2070-0237 (Print); 2070-0245 (Online). All rights reserved.

doi: http://dx.doi.org/10.3329/jsr.v5i3.13820 J. Sci. Res. 5 (3), 499-513 (2013)

\section{Introduction}

Proteins are complex molecules and therefore synthesis by cell free system is difficult. One of the alternative ways is to produce protein in heterologous host. Recombinant DNA technology has opened the door to a new world of biotechnological products for the production of heterologous proteins in microorganisms, like, for instance, pharmaceutical products and industrial enzymes. It is now possible to produce large quantities of proteins in industrial scale at low price and with constant high quality by means of recombinant DNA technology. In 1982, the first product of recombinant DNA technology was produced by Lilly [1], namely insulin, a life saving drug for diabetic patients. Since then many proteins and enzymes have been produced worldwide for food and medical purposes. In most cases, recombinant genes are expressed in heterologous host. The most commonly used and well studied organism for the heterologous expression of proteins is

\footnotetext{
*Corresponding author: mzalamgen@yahoo.com
} 
E. coli. However, a variety of alternative hosts have been developed as the nature of the recombinant proteins being expressed became more complex.

In this context, yeasts, Saccharomyces cerevisiae are very useful hosts because they have several advantages over other microorganisms such as: rapid growth, nonpathogenic, discrete cells, ability for replica plating, an accommodating DNA transformation system [2], well defined genetics, cheap and commercially available mutants. Moreover, many human genes related to disease have orthologs in yeast [3], meaning that the same genes have been conserved through time in species, maintaining the same or similar function. Many scientific studies show that nearly $50 \%$ of human genes implicated in heritable diseases have yeast homologs [4] or at least $31 \%$ of proteins encoded by yeast genes have human homologs. Moreover, cell cycle mechanisms, signal transduction, and metabolic and regulatory mechanisms between yeast and other eukaryotic organisms are conserved. The close homology to higher order eukaryotes and simplicity of yeast genetics allows the introduction of mammalian genes into yeast and the analysis of their function [5]. $S$. cerevisiae was the first eukaryote with the genome completely sequenced, with the possibility of being transformed with plasmids and to have gene knockouts strains [3]. Yeast has shifted molecular genetics research to a systems level approach of functionally characterizing parts of the genome. S. cerevisiae has also been used for centuries in food production, especially in bakery and brewing industries, and is Generally Recognized As Safe (GRAS) by the American Food and Drug Administration (FDA). By contrast, mammalian cells may contain oncogene or viral DNA, while other prokaryotic organisms may have toxic cell wall pyrogens (endotoxins). In addition, yeasts have the ability to perform eukaryotic processing steps during polypeptides synthesis. Most of the recombinant proteins produced in $S$. cerevisiae are intracellular, i.e., they are produced and retained within cell. These proteins may be produced in a soluble, biologically active form, or they can be insoluble and precipitate in the cell as inclusion bodies [6]. The recovery of both forms of proteins requires the disruption of the yeast cells as an initial step in the extraction and purification of proteins. Some of the examples in which direct intracellular expression have been successfully used to express heterologous gene products include the hepatitis B virus surface antigen (HBsAg) [7], human superoxide dismutase (hSOD) [8], fibroblast growth factor [9], human immunodeficiency virus type-1 (HIV1) env and gag polypeptides [10, 11], surface antigens of malaria parasites [12], rat cytochrome C [13], $\alpha 1$-antitrypsin proteinase inhibitor [14] and human viral surface glycoproteins [15]. Considering all the benefits and advantages as like eukaryotic system, yeast was selected for heterologous expression of protein.

Protein purification is a complex process requiring a high degree of skill and experience, and most protocols rely on finding particular properties of the protein in question, which can be used to gradually enrich the protein away from all the other proteins and components of the cell. Recently, a new range of techniques have come into general use which can speed up the process by cutting down the number of steps necessary, and which are broadly applicable to a range of proteins with very different 
properties. All these techniques involve adding extra amino acids to the protein that give it a new properties, namely to bind very tightly to a particular substrate. This specific binding can be used to isolate the protein away from all the other materials in the cell which do not bind this substance. The method is known as affinity chromatography. A common example is the use glutathione S- transferase (GST) tags. GST is an abundantly expressed $26 \mathrm{kDa}$ eukaryotic protein, and GST cloned from Schistosoma japonicum promotes solubility and permits purification of N-terminal fused proteins using glutathione sepharose [16]. When applied to the affinity medium, fusion proteins bind to the ligand and impurities are removed by washing with binding buffer. Fusion proteins are then eluted from the Glutathione Sepharose under mild, non denaturing conditions that preserve both protein antigenicity and function. The present study was intended to over expression of $\beta$ galactosidase protein (MW $116 \mathrm{kDa}$ ) in yeast with glutathione $\mathrm{S}$ transferase (GST) tag (MW $26 \mathrm{kDa}$ ) and optimization of purification condition. The full length $E$. coli $\beta$-galactosidase was selected as model protein because its presence and functional activity can be assessed by well known $\beta$-gal assay [17] before purification. Moreover very few information are available regarding larger GST tag protein [ $>100 \mathrm{kDa}]$ purification from yeast. So, in this paper we will show a detail protocol for purification of larger protein from the yeast using affinity chromatography technique.

\section{Materials and Method}

\subsection{Yeast strain, plasmid, media and growth condition}

The yeast Saccharomyces cerevisiae was used in this study for the heterologous over expression of $\beta$-galactosidase: the diploid strain CEN.PK2 (MATa/MAT $\alpha$, ura3-52/ura352, trp1-289/trp1-289, leu2-3_112/leu2-3_112, his3 $\Delta 1 /$ his3 $\Delta 1$, MAL2-8C/MAL2-8C, SUC2/SUC2) and the haploid strain BY4742 (MAT $\alpha$, his $3 \Delta 1$, leu2 $\Delta 0$, lys $2 \Delta 0$ and ura3 $\Delta 0$ ). The yeast strain CEN.PK2 without pGL-C1 plasmid also grown as control. The multicopy plasmid vector pGL-C1 carrying E. coli lacZ gene, producing $\beta$-galactosidase protein, was transformed in S. cerevisiae in the diploid CEN.PK2 strain under the control of the GPD promoter as a fusion with glutathione S-transferase (GST- $\beta$ gal). The pUKC815 plasmid containing the yeast phosphoglycerate kinase (PGK1) gene promoter and the N-terminal 33 amino acids fused in-frame to the $E$. coli lacZ gene coding for $\beta$ galactosidase was expressed in the haploid BY4742 strain. The plasmid pUKC815 was constructed by cloning a $0.9 \mathrm{~kb}$ ClaI-BamHI fragment from pUKC350 [18] into the plasmid YCp50 [19] digested with ClaI and BamHI, thereby generating pUKC814. A 3.2$\mathrm{kb}$ BamHI fragment from $\mathrm{pUKC} 350$ carrying the lacZ gene was then cloned into pUKC814 digested with BamHI, thereby generating pUKC815 [20]. All yeast strain were grown at $30^{\circ} \mathrm{C}$ in minimal medium $(0.67 \%$ bacto yeast nitrogen without amino acids, 100 $\mu \mathrm{g} / \mathrm{ml}$ of each of the required amino acids, $2 \%$ glucose and $2 \%$ bacto agar for solid medium). More specifically the yeast strain CEN.PK2 transformed with plasmid was 
grown in minimal media lacking tryptophan while haploid strain BY 4742 transformed with pUKC815 plasmid was grown in minimal medium lacking Uracil, and was preserved at $-80^{\circ} \mathrm{C}$ in $\mathrm{MM}$ with $40 \%$ glycerol.

\subsection{Sequencing and transformation of $\beta$-galactosidase (lacZ gene) protein}

In order to confirm the correct sequence of the lacZ gene within constructs, pGL-C1 plasmids were extracted using a miniprep kit (Fermentas) and then sequenced using specific primers. Whole genome DNA of yeast strain CEN.PK2 was extracted according to instruction of the Wizard ${ }^{\circledR}$ Genomic DNA Purification Kit (Promega) and Primers were designed using PerlPrimer v1.1.21 (http://perlprimer.sourceforge.net) and purchased from STAB VIDA (Portugal).

\section{Primer sequences: 5' $\rightarrow$ 3'}

Forward 1: TAATACGACTCACTATAGGG [Universal T7 promoter]

Reverse 1: CGGATACTGACGAAACGCCT

Forward 2: GATGAAGATCAGCCGTTTCC

Reverse 2: CCTATTGCTATAACCGCACT

Forward 3: TGGCAATTTAACCGCCAGTC

The lacZ gene was PCR amplified for sequencing using classic Sanger sequencing methods. For the PCR master mix, $0.125 \mu \mathrm{l} \mathrm{Taq}$ DNA polymerase $(1 \mathrm{U} / \mu \mathrm{l}), 2.5 \mu \mathrm{l}$ of $10 \mathrm{X}$ Buffer (500 mM KCl, $100 \mathrm{mM}$ Tris- $\mathrm{HCl}$ (pH 9.0), 1.0\% Triton X 100), $0.5 \mu$ l of dNTPs $(5 \mathrm{mM})$ and $0.5 \mu \mathrm{l}$ of each primer $(10 \mathrm{mM})$ were combined and brought to a final volume of $25 \mu \mathrm{l}$ per PCR reaction with sterile distilled water (milli-Q). The PCR protocol consisted of 30 cycles, of denaturing at $94^{\circ} \mathrm{C}$ for $60 \mathrm{~s}$, annealing at $55^{\circ} \mathrm{C}$ for $90 \mathrm{~s}$ and extension at $72^{\circ} \mathrm{C}$ for $60 \mathrm{~s}$ in a $\mathrm{MyCycler}^{\mathrm{TM}}$ thermal cycler (BIO-RAD). The PCR products were separated for 30-35 minutes at a constant voltage of $100 \mathrm{~V}$ alongside a DNA ladder (GeneRuler ${ }^{\mathrm{TM}} 50 \mathrm{bp}$ DNA ladder Plus, Fermentas). For gel preparation 0.70 $\mathrm{g}(1.4 \%)$ of agarose was dissolved in $50 \mathrm{ml}$ TAE $1 \mathrm{X}$ buffer with $0.5 \mu \mathrm{l}$ of ethidium bromide (EtBr). The sequencing of $L a c Z$ gene PCR amplicons was done by commercial provider STAB VIDA (Portugal).

\subsection{PCR product purification}

Enzyme contamination of DNA samples can interfere with subsequent downstream applications. In this study, QIAquick PCR Purification Kit from QIAGEN ${ }^{\circledR}$ was used to purify PCR amplicons. The first step of the protocol consisted in adding the binding buffer (PB; pH 7.5 and containing the chaotropic salt guanidine hydrochloride) to the samples. Then, the DNA solution was passed through the silica-gel membrane by centrifugation to bind the DNA, followed by a washing step with an ethanol-containing 
buffer (PE buffer) to remove salts. Finally, the DNA was eluted in a low-salt solution (EB buffer; $10 \mathrm{mM}$ Tris. $\mathrm{Cl}, \mathrm{pH} 8.5)$.

\subsection{Plasmids transformation}

Transformation of $S$. cerevisiae was performed using the lithium acetate (LiAc) method [21]. Briefly, overnight cultures were diluted in $10 \mathrm{~mL}$ (for 10 transformation reactions) of fresh medium at an $\mathrm{OD}_{600}$ of 0.05 . The cultures were grown at $30^{\circ} \mathrm{C}$ with $200 \mathrm{rpm}$ shaking until they reached to an $\mathrm{OD}_{600}$ of $0.4-0.5$. Cells were then harvested by centrifugation for 5 minutes at $4000 \mathrm{rpm}$. After washing with $5 \mathrm{~mL}$ of sterile milli-Q water, the pellet was resuspended in $500 \mu \mathrm{L}$ of $0.1 \mathrm{M} \mathrm{LiAc}$ solution. Around $50 \mu \mathrm{L}$ of cell suspension were transferred onto $1.5 \mathrm{~mL}$ eppendorf tubes and cells were pelleted by centrifugation at maximum speed for 15 seconds. The supernatant was discarded and the transformation reagents were added to the pellet in the following order: $240 \mu \mathrm{L} 50 \%$ (w/w) PEG, $36 \mu \mathrm{L} 1.0 \mathrm{M}$ LiAc, $25 \mu \mathrm{L}$ single-stranded carrier DNA $(2 \mathrm{mg} / \mathrm{mL})$ previously denatured and $50 \mu \mathrm{L}$ of an aqueous solution of the plasmid of interest (containing 0.1 $1 \mu \mathrm{g}$ of plasmid). The tubes were vortexed until a homogeneous suspension was obtained. The cells were then heat shocked in a water bath at $42^{\circ} \mathrm{C}$ for 30 to 40 minutes. Cells were then harvested by centrifugation at $5000 \mathrm{rpm}$ for 1 minute. The supernatant was discarded and the pellet was carefully resuspended in $100 \mu \mathrm{L}$ of sterile milli-Q water. Each suspension was plated in selective media plates and incubated at $30^{\circ} \mathrm{C}$, until transformant colonies were visible (about 3 - 4 days).

\subsection{Growth pattern of yeast transformed with lacZ gene}

The yeast strains transformed with the plasmid carrying the lacZ gene was grown at $30^{\circ} \mathrm{C}$ with $180 \mathrm{rpm}$ until late exponential phase (between 0.6 and $0.8 \mathrm{OD}_{600}$ ). The growth curves were obtained by inoculating the yeast coming from the same pre-inoculum at exponential phase (OD 0.5-0.7) into media to an initial $\mathrm{OD}_{600}$ of 0.02 cultured in $50 \mathrm{ml}$ Erlenmeyer flasks. The cultures were allowed to grow for the first 8 hours and then every hour aliquots of cultures were collected and the $\mathrm{OD}_{600}$ was measured with micro plate reader during the first day (around 20 hours) to fourth days (around 96 hours) until the cultures reached to stationary phase $\left(\mathrm{OD}_{600} \sim 2.5\right)$. Finally, the growth rate corresponding to the growth of yeast cells in exponential phase was calculated.

\section{6. $\beta$-galactosidase assay}

$\beta$-galactosidase activity was monitored as described by Sambrook and coworkers [17] with small modifications. Briefly, $10 \mathrm{ml}$ of pre - culture were inoculated with a distinct yeast colony grown in solid agar and the cultures were grown over night at $30^{\circ} \mathrm{C}$ with 180 rpm. The cultures were then inoculated with 3 replicate. Yeast cells expressing the 
plasmids were selected on minimal medium (lacking tryptophan) and inoculated with starting $\mathrm{OD}_{600} \sim 0.02$. Cells were then collected when the cultures reached $\mathrm{OD}_{600} \sim 1.5$, chilled on ice and span down at $4000 \mathrm{rpm}$ for 5 minutes. Then the cells were washed twice with $1 \mathrm{ml}$ of PBS and finally resuspended in $250 \mu \mathrm{L}$ of PBS and frozen immediately at $80^{\circ} \mathrm{C}$ and assayed later. Cell suspensions were thawed on ice and resuspended with $300 \mu \mathrm{l}$ PBS, 1/3 volume of glass beads, $1 \mathrm{mM}$ PMSF and tablets of protease inhibitors (ROCHE) were added and vortexed 1 minute for 5 times using Precellys ${ }^{\circledR} 24$ bead-beating homogenizer and chilled on ice for 1 minute between bursts. The supernatant was then removed carefully avoiding foam and transferred to a new previously refrigerated Eppendorf tube. The protein extract was clarified by centrifugation for 15 minutes at $13000 \mathrm{rpm}$ at $4^{\circ} \mathrm{C}$. A $2.5 \mu \mathrm{l}$ extract was transferred to another microtube and adjusted the total volume to $0.5 \mathrm{ml}$ with $\mathrm{Z}$ buffer $\left(16.1 \mathrm{~g} \mathrm{Na}_{2} \mathrm{HPO}_{4}-7 \mathrm{H}_{2} \mathrm{O}, 5.5 \mathrm{~g} \mathrm{NaH}_{2} \mathrm{PO}_{4}-\mathrm{H}_{2} \mathrm{O}, 0.75 \mathrm{~g}\right.$ $\mathrm{KCl}, 0.246 \mathrm{~g} \mathrm{MgSO}_{4}-7 \mathrm{H}_{2} \mathrm{O}, \mathrm{H}_{2} \mathrm{O}$ to 1 liter and add $2.7 \mathrm{ml} \beta$-mercaptoethanol $270 \mathrm{ul} / 100 \mathrm{ml}$ but only before use). $\beta$-mercaptoethanol was added just before use at the rate of 270 $\mu \mathrm{l} / 100 \mathrm{ml}$. For thermal inactivation the mixture was incubated at $54^{\circ} \mathrm{C}$ for different test times $(0,2,4,6,10$ and $15 \mathrm{~min})$ and then left on ice for 30 minute. The reaction tube was incubated at $37^{\circ} \mathrm{C}$ for $5 \mathrm{~min}$ and the reaction initiated by adding $0.1 \mathrm{~mL}$ of ONPG stock solution. The time lapse between two tubes was 10 seconds. Each reaction was then allowed to proceed for 5 minute. Finally the reaction was terminated by adding $0.25 \mathrm{ml}$ of $\mathrm{Na}_{2} \mathrm{CO}_{3}$ stock solution (again $10 \mathrm{sec}$ time lapse between tubes). The optical density was measured at $420 \mathrm{~nm}$ using a Microplate Absorbance Reader (iMark, BIO-RAD). A 200 $\mu \mathrm{L}$ of reaction sample was loaded in 96 well plates and $\mathrm{Z}$ buffer was used as blank. The protein concentration was measured using Pierce ${ }^{\circledR}$ BCA Protein Assay Kit (Thermo scientific) following Microplate procedure. The protein mixture, whenever necessary, was diluted in 1X PBS at 1: 5 ratios and the absorbance was measured at $575 \mathrm{~nm}$ on a plate reader. The activity of the $\beta$-galactosidase was expressed according to the following expression:

$$
\left(\mathrm{OD}_{420} \times 0.085\right) /(0.0045 \times \text { Protein } \times \text { Extract volume } \times \text { Time })
$$

$\mathrm{OD}_{420}$ is the value of optical density of o-nitrophenol measured at $420 \mathrm{~nm}$. The factor 0.85 corrects for the reaction volume. The factor 0.0045 is the optical density of a 1 $\mathrm{nmole} / \mathrm{ml}$ solution of o-nitrophenol. Protein concentration is expressed as $\mathrm{mg} / \mathrm{ml}$. Extract volume is the volume assayed in milliliters. Time is in minutes. Specific activity was expressed as nmoles/minute/mg protein.

\subsection{Protein extraction}

Yeasts cells were cultured in $500 \mathrm{ml}$ Erlenmeyer flask and around $50 \mathrm{ml}$ of cells were collected in each falcon tube when the cultures reached $\mathrm{OD}_{600} \sim 1.5$, chilled on ice and span down at $4000 \mathrm{rpm}$ for 5 minutes. Then the cells were washed twice with $5 \mathrm{ml}$ of $1 \mathrm{X}$ 
PBS and finally resuspended in $250 \mu \mathrm{L}$ of $1 \mathrm{X}$ PBS and frozen immediately at $-80^{\circ} \mathrm{C}$. For the extraction of protein (soluble and insoluble) from $S$. cerevisiae strain CEN.PK2 carrying pGL-C1 plasmids, frozen cells were defrosted on ice and $5 \mathrm{~mL}$ of $1 \mathrm{X}$ PBS $(8.2 \mathrm{~g}$ $\mathrm{NaCl}$, 0. $2 \mathrm{~g} \mathrm{KCl}, 1.41 \mathrm{~g} \mathrm{Na}_{2} \mathrm{HPO}_{4} ; 0.24 \mathrm{~g} \mathrm{KH}_{2} \mathrm{PO}_{4}$; Volume adjusted to $1000 \mathrm{~mL}$ of distilled water and $\mathrm{pH}$ was adjusted to 7.4 with $\mathrm{HCl}$ and sterilized by autoclaving) was added and the pellets re-suspended by vortexing. Then $1 \mathrm{mM}$ PMSF and a Roche Protease inhibitor cocktail were added. Around $\sim 1 / 3$ volume of glass beads $(0.1 \mathrm{~mm})$ were added to the mixture and cells were lysed by vortexing at high speed, 8 times for 30 seconds, with cooling on ice for 1 minute between each vortexing step. Then the cells were centrifuged at $3000 \mathrm{rpm}$ for 5 minutes at $4^{\circ} \mathrm{C}$. Supernatants (whole cell lysates) were transferred to a new falcon tube and further fractioned by centrifugation at $11000 \mathrm{rpm}$ for $20 \mathrm{~min}$ at $4^{\circ} \mathrm{C}$. The supernatants were collected and filtered with a $0.45 \mu \mathrm{m}$ filter into a new $15 \mathrm{~mL}$ falcon tube ("total soluble" protein) and a small fraction $(100 \mu \mathrm{L})$ was saved for SDS-PAGE and western blot analysis. The pellets (insoluble under native condition) were re-suspended in $5 \mathrm{~mL}$ denaturing buffer (1X PBS with 8M urea) and centrifuged at $11000 \mathrm{rpm}$ for $20 \mathrm{~min}$ at $4^{\circ} \mathrm{C}$. The supernatants were collected and filtered with a $0.45 \mu \mathrm{m}$ filter to a new $50 \mathrm{~mL}$ falcon tube ("total insoluble" protein) and a small fraction $(100 \mu \mathrm{L})$ was saved for SDSPAGE and western blot analysis.

\subsection{Purification of GST tagged $\beta$ galactosidase protein from yeast extract}

Affinity chromatography is commonly used to purify a protein of interest from total protein preparations. For this, affinity tags are cloned into recombinant proteins for affinity purification and to improve protein solubility. A large number of tags have been developed for protein production. In the present study a GST tag was fused with the lacZ gene in plasmid pGL-C1 for expression in CEN.PK2 yeast strain. This allowed for purification of $\beta$-galactosidase protein with glutathione sepharose beads.

\subsection{Protein purification by affinity chromatography}

In the present study the GST- $\beta$ galactosidase protein was purified using Glutathione Sepharose 4B (GE Healthcare, Bio-Sciences AB, Sweden) medium. After the fusion protein is bound to the resin, it was eluted under rather mild conditions using free reduced glutathione (between $10-40 \mathrm{mM}$ ) at neutral $\mathrm{pH}$.

The Glutathione Sepharose medium was prepared according to manufacturer protocol. About $400 \mu \mathrm{L}$ of prepared Sepharose 4B resin (50\% slurry) was incubated overnight with total soluble protein with gentle slurry mixing. The day after a Poly-Prep ${ }^{\circledR}$ Chromatography Column (Bio-rad) was washed with one column volume of milli-Q water and then equilibrated with one column volume of binding buffer (1X PBS). Then, the proteins were mixed overnight with Sepharose beads and poured into the column and the flow through was collected in a $15 \mathrm{~mL}$ falcon tube. The column was then washed with one 
column volume of $1 \mathrm{X}$ PBS (washing buffer) and the flow through was collected in another $15 \mathrm{~mL}$ falcon tube. The bound protein was then eluted with $5 \mathrm{ml}$ of elution buffer [for $100 \mathrm{~mL}$ preparation $0.61 \mathrm{~g}$ Tris-Base $(50 \mathrm{mM}), 0.31 \mathrm{~g}$ Reduced Glutathione $(10 \mathrm{mM})$, adjust volume and $\mathrm{P}^{\mathrm{H}}$ at 8 with $\mathrm{HCl}$ and then sterilized by filtration $\left.(0.20 \mu \mathrm{m})\right]$. The eluted protein fraction was collected into 5 Eppendorf tubes $(1.5 \mathrm{ml}$ each fraction) in order to identify the fraction which contained the higher amount of purified protein. Finally all eluted protein merge together in a single falcon tube. The protein was then ready for SDSPAGE and western blotting analysis.

\subsection{Protein purification profile}

The purification profile was monitored by Sodium Dodecyl Sulfate-Poly Acrylamide Sel Electrophoresis (SDS-PAGE). Each SDS-PAGE gel is composed by a resolving gel with a percentage of acrylamide adapted to the size of the target protein. To improve the resolution, proteins first pass through a stacking gel polymerized on the top of the resolving gel. The stacking gel has lower $\mathrm{pH}$ and acrylamide concentration (4\%) as well as different ionic strength, which allows the proteins to be concentrated during the first minutes ( 30 $\mathrm{min}$ ) of electrophoresis, before entering the resolving portion of the gel. Since the GST- $\beta$ galactosidase protein has a MW of $\sim 142 \mathrm{kDa}, 10 \%$ resolving gels were used successfully after several trials. During gel preparation Tris- $\mathrm{HCl}$ was used as buffer to absorbs counter ions $\left(\mathrm{H}^{+}\right.$and $\left.\mathrm{OH}^{-}\right)$keeping the solution in a stable $\mathrm{pH}$ level. For gel polymerization, APS (ammonium persulfate at $10 \mathrm{mg} / 100 \mathrm{ml}$ ), a source of free radicals was used as initiator of gel formation and TEMED (N, N, N', N'-tetramethylethylene diamine), a stabilizer of free radicals, was used to improve polymerization. The recipe of 2 SDS-PAGE gels was for stacking gel (4\%) [milli-Q water $3.465 \mathrm{ml}$, SDS (10\% w/v) 50 $\mu$, Tris- $\mathrm{HCl} 1.0 \mathrm{ml}(0.625 \mathrm{M}, \mathrm{pH} 6.8)$, Acrilamide/ Bis acrilamide (40\% stock) $0.5 \mathrm{ml}$, APS $(10 \mathrm{mg} / 100 \mu \mathrm{l}) 25 \mu \mathrm{l}$, TEMED $20 \mu \mathrm{l}$ ] and for resolving gel (10\%) [Water (milli-Q)

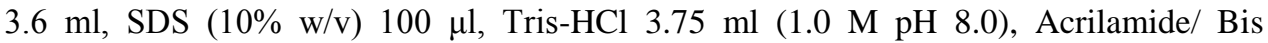
acrilamide (40\% stock) $2.5 \mathrm{ml}$, APS $(10 \mathrm{mg} / 100 \mu \mathrm{l}) 50 \mu \mathrm{l}$, TEMED $20 \mu \mathrm{l}]$ and Bio-Rad ${ }^{\circledR}$ SDS-PAGE gel apparatus were used. The Protein samples for SDS-PAGE were prepared by adding $6 \mathrm{X}$ loading buffer (for $10 \mathrm{ml}$ buffer composition was $6 \mathrm{ml}$ Glyercol, $0.5 \mathrm{M} 1.2$

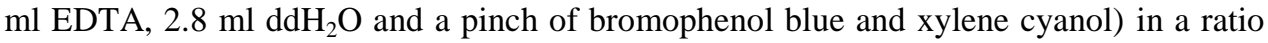
of $1: 6$, followed by denaturing the samples for seven minute at $95^{\circ} \mathrm{C}$. Around $15 \mu \mathrm{L}$ of protein preparation were loaded into the gel pockets along with a pre-stained protein marker and the gels were run with 1X SDS running buffer ( for $1 \mathrm{~L}$ Tris $6.05 \mathrm{~g}, 8.76 \mathrm{~g}$ $\mathrm{NaCl}$ with $\mathrm{pH}$ adjusted to 7.5 ) at $80 \mathrm{~V}$ for the first 30 minutes until the samples reached to the stacking gel. Then, the voltage was increased to $130 \mathrm{~V}$ and the gels were run for 2 hours until the dye front reached the bottom of the gel. The gel was then carefully removed and stained with Coomassie Brilliant Blue dye for 1-2 hours and destained overnight with destain solution. 


\subsection{Western blot analysis}

Western blotting confirms the presence of desired protein in yeast lysates. In the present study, after electrophoresis, proteins were electro blotted onto nitrocellulose membranes (Amersham Hybond ECL) prior to immunodetection. Soluble and insoluble protein fractions were analyzed under reducing conditions using 10\% SDS-PAGE, as described above, and blotted onto a nitrocellulose membrane. For this, six sheets of $3 \mathrm{MM}$ paper (Whatman) and blotting membranes were cut to gel dimensions. Membranes were prehydrated in distilled water and 3 sheets of 3 MM paper and hydrated in 1X TGM buffer [25mM Tris-Base (3.03 g/L), $193 \mathrm{mM}$ Glycine (14.4g/L), $20 \%$ Methanol (200 mL) and volume adjusted to $1000 \mathrm{~mL}$ of distilled water]. Then papers were placed above pads on the anode of the transfer system, and a "sandwich" was assembled by laying down the gel on top of the paper sheets. The blot was run for $100 \mathrm{~min}$ at $100 \mathrm{~V}$ at $4^{\circ} \mathrm{C}$ in $\mathrm{TGM}$ buffer using a BIO-RAD ${ }^{\circledR}$ wet transferring system (assembled according to manufacturer's instructions). The membranes were removed carefully and washed 2 times with $1 \mathrm{X}$ TBS and blocked in 1X TBS (for $1 \mathrm{~L}$ Tris $6.05 \mathrm{~g}, 8.76 \mathrm{~g} \mathrm{NaCl}$ with $\mathrm{pH}$ adjusted to 7.5) with $3 \%$ non-fat milk for 30 minutes at room temperature with gentle agitation. After removing blocking agent, the membranes were washed two times for 5 minutes with $1 \mathrm{X}$ TBS. Following the blocking and washing, the primary antibody (anti $\beta$-galactosidase IgG fraction A-11132 raised in rabbit, Molecular probes) was added (1:5000) to the membranes in a solution of $3 \%$ non-fat dry milk in $1 \mathrm{X}$ TBS. For this, the membranes were placed in heat sealable plastic bags, and each membrane was incubated overnight at $4^{\circ} \mathrm{C}$ with agitation. After the overnight incubation, the membranes were washed twice for 5 minutes with $1 \mathrm{X}$ TBS to remove unbound primary antibody.

The membranes were incubated with the secondary antibody, a mouse anti-rabbit antibody reactive against the primary antibody and coupled to a fluorochrome that allows subsequent visualization. A 1:10,000 dilution of mouse anti-rabbit antibody was prepared in $1 \mathrm{X}$ TBS and 3\% non-fat dry milk. Again, incubations were performed in a plastic tray, which were then wrapped in aluminium foil (to avoid fluorochrome degradation by light) at room temperature for 2 hours with gentle agitation. Following, three washes were performed with $1 \mathrm{X}$ TBS-Tween ( $1 \mathrm{ml}$ of Tween-20 in 1L of 1X TBS buffer), for 15 minutes each time. The membranes were then washed with distilled water and analyzed at $700 \mathrm{~nm}$ (anti rabbit) using an Odyssey Li-COR fluorescence imager (Bioscience).

\section{Results and Discussion}

\subsection{Growth of the yeast carrying plasmid transformed recombinant GST-Lac Z gene}

The growth of $S$. cerevisiae strains CEN.PK2 and BY4742, transformed with plasmid pGL-C1 and pUKC815 respectively and the control strain CEN.PK2 without transformed plasmid was monitored by measuring the optical density at different time points at wave length $595 \mathrm{~nm}$ (Table 1). All the yeast strains showed a similar pattern of growth curve 
(Fig. 1) and the statistical analysis revealed that there is no significant difference of growth rate between yeast strains.

Table 1. Optical density (OD 595nm) of yeast strain at different hours of incubation.

\begin{tabular}{|c|c|c|c|c|}
\hline \multirow[b]{2}{*}{$\begin{array}{c}\text { Time } \\
\mathrm{h}\end{array}$} & \multicolumn{3}{|c|}{ OD $595 \mathrm{~nm}$ at different hours of incubation } & \multirow[b]{2}{*}{ Statistical analysis } \\
\hline & $\begin{array}{c}\text { CEN.PK2 } \\
\text { control (T1) }\end{array}$ & $\begin{array}{c}\text { CEN.PK2 } \\
\text { (T2) }\end{array}$ & $\begin{array}{l}\text { BY4742 } \\
\text { (T3) }\end{array}$ & \\
\hline 0 & 0.021 & 0.021 & 0.021 & \multirow{18}{*}{$\begin{array}{l}\text { Statistical analysis was done using unpaired } \\
\text { ' } t \text { ' test of growth rate per hour from } 9 \text { to } 20 \\
\text { hours : } \\
\text { SED (T1,T2) } 0.0249 \\
T \text { test }(\mathrm{T} 1, \mathrm{~T} 2) \text { calculated : } 0.803 \\
\text { SED (T2,T3) }=0.0235 \\
\text { T test (T2,T3) calculated : } 0.805 \\
\text { By comparing calculated ' } \mathrm{t} \text { ' value with table } \\
\text { ' } t \text { ' value for } 22 d . f\{(12-1)+(12-1)\} \text { at } 5 \% \\
\text { probability (table ' } t \text { ' value }=2.074) \\
t_{\text {cal }}<t_{\text {tab }} \text { at } 22 d . f \\
\text { As calculated ' } t \text { ' is smaller than tabulated ' } \mathrm{t} \text { '. } \\
\text { We conclude that the difference in growth } \\
\text { rate of yeast is not significant. }\end{array}$} \\
\hline 8 & 0.950 & 1.000 & 0.949 & \\
\hline 9 & 1.221 & 1.276 & 1.234 & \\
\hline 10 & 1.575 & 1.637 & 1.613 & \\
\hline 11 & 1.806 & 1.896 & 1.857 & \\
\hline 12 & 2.187 & 2.153 & 1.991 & \\
\hline 13 & 2.517 & 2.374 & 2.128 & \\
\hline 14 & 2.416 & 2.305 & 2.205 & \\
\hline 15 & 2.474 & 2.309 & 2.180 & \\
\hline 16 & 2.522 & 2.340 & 2.224 & \\
\hline 17 & 2.596 & 2.442 & 2.234 & \\
\hline 18 & 2.683 & 2.467 & 2.302 & \\
\hline 19 & 2.688 & 2.431 & 2.171 & \\
\hline 20 & 2.723 & 2.533 & 2.255 & \\
\hline 32 & 2.876 & 2.845 & 2.236 & \\
\hline 40 & 3.446 & 3.126 & 2.263 & \\
\hline 64 & 3.180 & 2.909 & 2.545 & \\
\hline 106 & 3.709 & 3.457 & 2.691 & \\
\hline
\end{tabular}

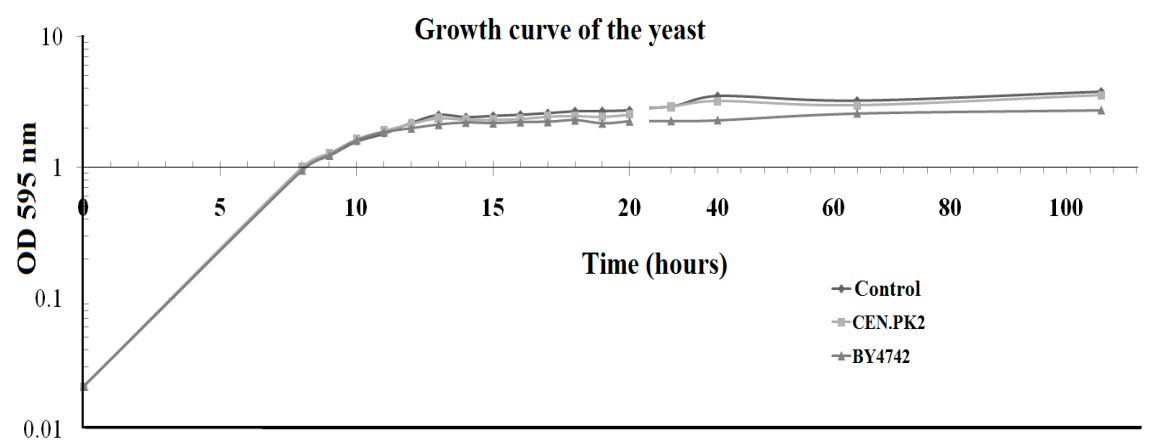

Fig. 1. Growth curves of Saccharomyces cerevisiae strain CEN.PK2 carrying pGL-C1 plasmid compared to control strain CEN.PK2 without plasmid and strain BY4742 carrying pUKC815 plasmid without GST tag. 


\section{2. $\beta$-galactosidase assay}

The $\beta$-galactosidase ( $\beta$-gal) reporter system was used previously to test on the fidelity of protein synthesis. This test is based on the fact that if misincorporation of amino acids occurs in the $\beta$-gal protein then the thermostability of the enzyme will decrease. In the present study we observed a decrease in activity of the $\beta$-galactosidase over heat inactivation time, the strongest decrease of enzymatic activity was observed after 6 minutes of heat inactivation (Fig. 2). The enzyme $\beta$-galactosidase ( $\beta$-gal) has an active quaternary structure and it is an efficient reporter protein for sense codon misreading due to the negative effects of the misincorporation on the thermostability of the enzyme [22]. In the present study $\beta$ gal shows positive result for both strain and $\beta$ galactosidase from yeast cells did not show visible effects on the heat stability of the expressed enzyme. Otherwise, the number of amino acids misincorporations in GST- $\beta$ gal was not sufficient or absent to cause a pronounced heat stability difference. However, further mass spectrometry based peptide analysis are necessary to confirm these results.

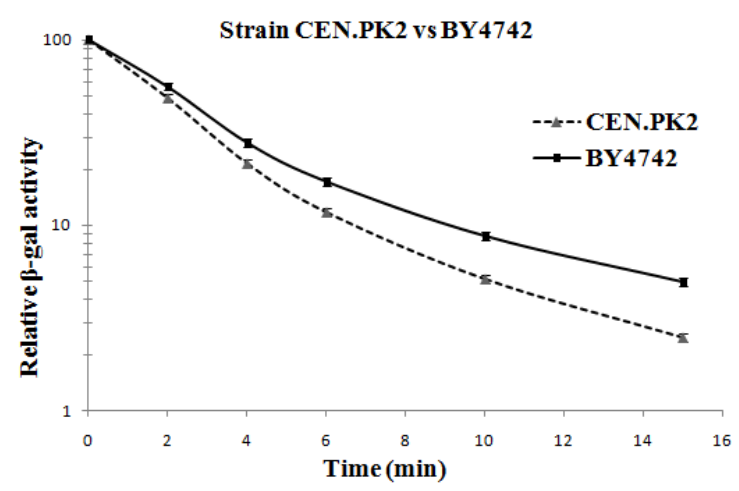

Fig. 2. Relative $\beta$-galactosidase activity of yeast strain CEN.PK2 carrying pGL-C1 plasmid and BY4742 strain carrying pUKC815 plasmid.

\subsection{SDS-PAGE and western blot of $\beta$-galactosidase}

After SDS-PAGE (Fig. 3A) analysis, intense bands in soluble protein were observed in the strain CEN.PK2 carrying pGL-C1 plasmid only. Other strain does not contain GST tag, so the affinity purification did not work. The intensity of bands in insoluble fraction was much weaker. The presence of GST- $\beta$ galactosidase protein was confirmed by western blotting and immuno detection (Fig. 3B) with a rabbit monoclonal antibody raised against $E$. coli $\beta$-galactosidase. The protein was detected both in the soluble and insoluble fractions. However, the intensity of bands in insoluble fraction was very weak. 


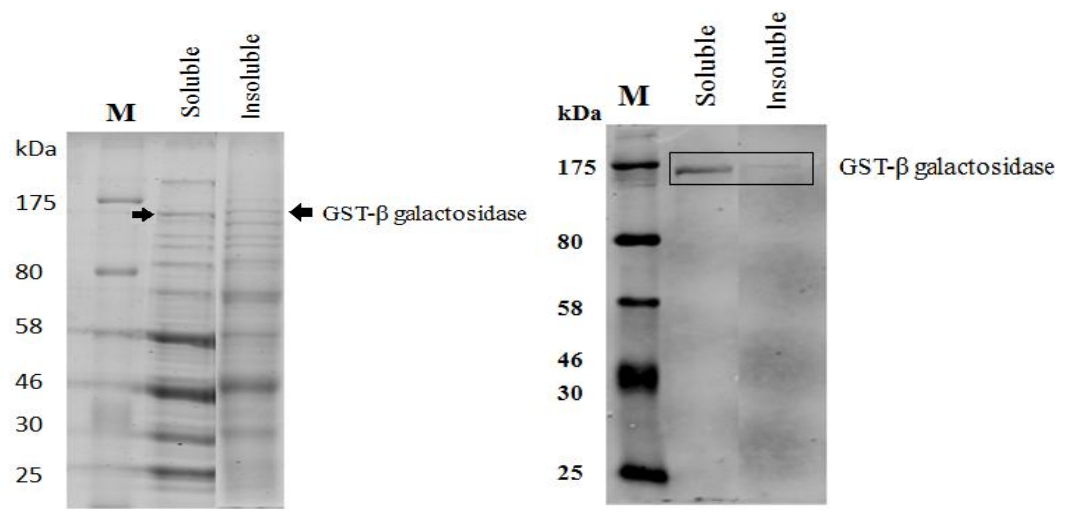

Fig. 3. SDS-PAGE (A) and Western blot (B) analysis showing of whole protein extract from yeast strain CEN.PK2 carrying plasmid pGL-C1. $1^{\text {st }}$ lane indicates M- marker, $2^{\text {nd }}$ lane - soluble and $3^{\text {rd }}$ lane - insoluble protein extract respectively. The rectangle in figure B indicates the position of GST$\beta$ galactosidase protein confirmed by western blotting.

\subsection{Purification of $\beta$-galactosidase protein from saccharomyces cerevisiae}

The $\beta$-galactosidase protein produced from lacZ gene has a molecular weight of $\sim 116 \mathrm{kDa}$ and the fusion with GST increase the molecular weight to $\sim 142 \mathrm{kDa}$. The GST binds to resin immobilized glutathione, and this property was successfully used for affinity purification of GST tagged proteins. The fusion protein bound to the glutathione sepharose beads, was eluted under mild conditions using free reduced glutathione (10 $\mathrm{mM}$ ) at neutral $\mathrm{pH}$. Most of the GST- $\beta$ galactosidase protein was soluble (Fig. 4B), the
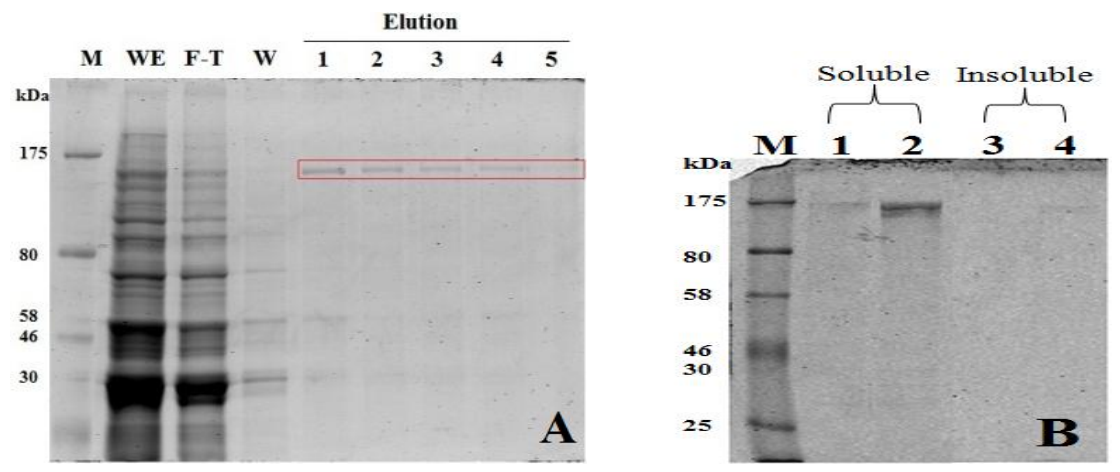

Fig. 4. A) SDS-PAGE showing purified GST- $\beta$ galactosidase protein from Saccharomyces cerevisiae strain CEN.PK2. Lanes (from left to right) showing : M- protein marker, WE - Whole extract, FT- Flow through, W- Wash with PBS and Elution fraction 1, 2, 3, 4 and 5. The red rectangle shows the band of GST- $\beta$ galactosidase protein in the soluble eluted fraction. B) SDSPAGE showing the concentrated protein centrifuged for 90 minutes (lane 1,3) and 150 minutes (lane 2, 4 respectively). $15 \mu 1$ of sample was loaded in 10\% PAGE gel whereas lane $1 \& 2$ indicate $\beta$-galactosidase protein from soluble and lane $3 \& 4$ indicate from insoluble extract. 
amount of protein extracted from the inclusion bodies was very little. The purified GST- $\beta$ galactosidase protein from the yeast strain CEN.PK2 was successively filtered and concentrated using Amicon ${ }^{\circledR}$ Ultra centrifugal (15 mL) 3000 MWCO devices (Millipore). A small fraction of the protein was loaded on a SDS-PAGE to check the protein purity. SDS-PAGE analysis (Fig. 4B) shows the presence of $\beta$ galactosidase protein in solution. The concentration of GST- $\beta$ galactosidase protein was quantified using NanoDrop ${ }^{\mathrm{TM}}$ spectrophotometer and was recorded $0.57 \mathrm{mg} / \mathrm{ml}$.

One of the objectives of this study was to optimize the GST- $\beta$ gal purification protocol. The 26-kD GST tag is short (218 aa) [23] and is frequently used as a fusion in molecular biology research. The study from Pawel and co-workers [24] defined soluble protein as the fraction that stayed in solution, did not oligomerize strongly and was stable (did not precipitate or aggregate), while insoluble proteins are defined as those that cannot stay in solution without denaturing agents like urea. Our $\beta$-galactosidase protein was successfully purified from the soluble protein extracts of yeast strain CEN.PK2 lysates. However, the GST- $\beta$ galactosidase protein purified from the insoluble fraction was not sufficient for SDS-PAGE gel and western blotting analysis. Several trials following different protocols $[15,25]$ to solubilize and purify the GST- $\beta$ gal from inclusion bodies were carried out using lysis buffers containing DTT, Triton-X (1\%), N-lauroylsarcosine sodium salt (sarkosyl) or $\mathrm{NaCl}(1 \mathrm{M})$, but they were not successful. A likely reason for these results is that the GST tag increases solubility of $\beta$-galactosidase. Indeed, a study from Kim and Lee [26] showed that GST can act as a solubility tag. Another study [27] suggests that the GST tag has to be folded properly in order to bind glutathione and should be purified under non denaturing conditions. In the present study a very faint band was observed in the insoluble fraction $\beta$-galactosidase treated with $8 \mathrm{M}$ urea. Therefore, the GST tag may solubilize $\beta$-galactosidase and urea may prevent its purification by denaturing GST.

\section{Conclusion}

In conclusion, this work showed a simple and standard protocol to perform recombinant large GST fusion protein $(>100 \mathrm{kDa})$ from yeast using affinity chromatography technique. This protocol also suggests that the growth of the yeast and the enzymatic activity does not alter due to GST tag and could be applied to a large variety of GST-fused proteins from yeast. Further studies would be necessary with other recombinant protein in order to get more consistent result.

\section{Acknowledgements}

This work was supported by the RNA Biology Laboratory, Department of Biology, University of Aveiro, Portugal. MZ Alam was involved in all aspects of the experimental design, works, data collection, analysis and interpretation. MS initiated the study, participated in its design and coordination. LR participated in expression work, 
coordinated the purification experiments and analyzed the data. AI drafted the manuscript and checked statistical analysis. All authors contributed to the final version of the manuscript.

\section{References}

1. See, G. Walsh, Biopharmaceuticals, Trends Biotechnol. 23, 553 (2005).

2. J. R. Broach, E. W. Jones, and J. R. Pringle (Eds.), The Molecular and Cellular Biology of the yeast Saccharomyces, Vol. 1. Genome Dynamics, Protein Synthesis, and Energetics (Cold Spring Harbor Laboratory Press, Cold Spring Harbor, NY, 1991).

3. S. L. Forsburg, Nature Review Genetics 2, 659 (2001). http://dx.doi.org/10.1038/35088500

4. L. H. Hartwell, Bioscience Reports 24, 523 (2004). http://dx.doi.org/10.1007/s10540-005-2743-6

5. F. Sherman, Methods Enzymology 350, 3 (2002). http://dx.doi.org/10.1016/S0076-6879(02)50954-X

6. F. Garrido, U. C. Banerjee, Y. Chisti, and M. Moo-Young, Bioseparation 4, 319 (1994). PMid:7765495

7. P. Valenzuela, A. Medina, W. J. Rutter, G. Ammerer, and B. D. Hall, Nature 298, 347 (1982). http://dx.doi.org/10.1038/298347a0

8. R. A. Hallewell, R. Mills, P. T. Olson, R. Blacher, S. Rosenberg, F. Otting, F. R. Masiarz, and C. J. Scandella, Biotechnology 5, 363 (1987). http://dx.doi.org/10.1038/nbt0487-363

9. P. J. Barr, L. S. Cousens, C. T. Lee-Ng, A. Medina-Selby, F. R. Masiarz, R. A. Hallewell, S. H. Chamberlain, J. D. Bradley, D. Lee, and K. S. Steimer, J. Biol. Chem. 263, 16471 (1988). PMid:2460449

10. I. C. Bathurst, N. Chester, H. L. Gibson, A. F. Dennis, K. S. Steimer, and P. J. Barr, J. Virol. 63 (7), 3176 (1989). PMid:2657103 PMCid:250878

11. P. J. Barr, K. S. Steimer, E. A. Sabin, D. Parkes, C. George-Nascimento, J. C. Stephans, M. A. Powers, A. Gyenes, G. A. Van Nest, and E. T Miller, Vaccine 5 (2) 90 (1987). http://dx.doi.org/10.1016/0264-410X(87)90053-3

12. P. J. Barr, H. L. Gibson, V. Enea, D. E. Arnot, M. R. Hollingdale, and V. J. Nussenzweig, Exp. Med. 165, 1160 (1987). http://dx.doi.org/10.1084/jem.165.4.1160

13. J. M. Clements, L. I. O'Connell, S. Tsunasawa, and F. Sherman, Gene 83, 1 (1989). http://dx.doi.org/10.1016/0378-1119(89)90398-3

14. X. H. Hu, M. H. Wang, T. Tan, J. R. Li, H. Yang, L. Leach, R. M. Zhang, and Z. W. Luo, Genetics 175, 1479 (2007). http://dx.doi.org/10.1534/genetics.106.065292

15. E. Ciplys, D. Samuel, M. Juozapaitis, K. Sasnauskas, and R. Slibinskas, Microb Cell Fact. 10, 37 (2011). http://dx.doi.org/10.1186/1475-2859-10-37

16. D. B. Smith, and K. S. Johnson, Gene 67, 31 (1988). http://dx.doi.org/10.1016/0378-1119(88)90005-4

17. J. Sambrook, E. F. Fritsch, and T. Maniatis, Molecular cloning: a laboratory manual, $2^{\text {nd }}$ ed. (Cold Spring Harbor Laboratory Press, NY, 2008). PMCid:2689524

18. M. Firoozan, C. M. Grant, J. A. B. Duarte, and M. F. Tuite, Yeast 7, 173 (1991). http://dx.doi.org/10.1002/yea.320070211

19. M. D Rose, R. Novick, J. H. Thomas, D. Botstein, and G. R Fink, Gene 60, 237 (1987). http://dx.doi.org/10.1016/0378-1119(87)90232-0

20. I. Stansfield, Akhmaloka, and M. F. Tuite, Current genetics 27, 417 (1995). http://dx.doi.org/10.1007/BF00311210

21. R. D. Gietz and R. A. Woods, Methods in Enzymology 350, 87 (2002). http://dx.doi.org/10.1016/S0076-6879(02)50957-5

22. E. W. Branscomb and D. J. Galas, Nature 254, 161 (1975). http://dx.doi.org/10.1038/254161a0 
23. J. Jordan Lichty, L. J. Malecki, D. H. Agnew, D. J. Michelson-Horowitz, and S. Tan, Protein Expression and Purification 41, 98 (2005). http://dx.doi.org/10.1016/j.pep.2005.01.019

24. P. Smialowski, J. Antonio, Martin-Galiano, A. Mikolajka, T. Girschick, T. A. Holak, and D. Frishman, Bioinformatics 23 (19), 2536 (2007).

http://dx.doi.org/10.1093/bioinformatics/btl623

25. D. Park, S. Kim, M. Nam, G. Kim, J. Kim, and H. Rhim, BMB reports 44 (4), 279 (2011).

26. S. Kim and S. B Lee, Protein Expr. Purif. 62, 116 (2008).

http://dx.doi.org/10.1016/j.pep.2008.06.015

27. A. Malhotra, Methods in enzymology 463, 239 (2011).

http://dx.doi.org/10.1016/S0076-6879(09)63016-0 